\title{
Determination of diflubenzuron residues in milk and cattle tissues
}

\author{
[Determinação de resíduos de diflubenzuron em leite e tecidos bovinos] \\ S.A.V. Tfouni ${ }^{1}$, R.P.Z. Furlani ${ }^{1}$, L.B. Carreiro ${ }^{1}$, I.S.D. Loredo ${ }^{1}$, A.G. Gomes ${ }^{2}$, L.A. Alves ${ }^{3}$, \\ R.S.S. Mata ${ }^{3}$, A.M.D. Fonseca ${ }^{3}$, R.M.S. Rocha ${ }^{3}$ \\ ${ }^{1}$ Instituto de Tecnologia de Alimentos - ITAL - Campinas, SP \\ ${ }^{2}$ Universidade Federal de Goiás - Goiânia, GO \\ ${ }^{3}$ Champion Farmoquímico Ltda - Anápolis, GO
}

\begin{abstract}
Diflubenzuron (DFB) is used to control ectoparasitic infestation by inhibiting larvae development in the manure and feces of treated animals. It is also currently been used to control tick infestations. In this study, milk and tissues from cattle treated orally with DFB for a 77-120 day period with a commercial product containing the compound were analyzed for the presence of residues. DFB residues were determined by using extraction with acetonitrile, cleanup with C18 SPE and chromatographic analysis by HPLC with UV detection (254nm). DFB was not detected in any of the analysed samples $\left(<0.006 \mathrm{mg} \mathrm{kg}^{-1}\right.$ for fat, $<0.014 \mathrm{mg} \mathrm{kg}^{-1}$ for muscle, $<0.015 \mathrm{mg} \mathrm{kg}^{-1}$ for kidney, $<0.016 \mathrm{mg} \mathrm{kg}^{-1}$ for liver and $<0.0006 \mathrm{mg} \mathrm{kg}^{-1}$ for milk). In this manner, the use of this compound, according to the manufacturer's suggested doses may result in cattle milk, liver, kidneys, fat and muscles being considered safe regarding the presence of DFB residues.
\end{abstract}

Key words: diflubenzuron, larvicide, veterinary drug, cattle tissue, milk

\section{RESUMO}

O diflubenzuron $(\mathrm{DFB})$ é um inibidor de desenvolvimento de insetos que inibe a síntese de quitina com atividade ovicida e larvicida e está sendo utilizado na pecuária para o controle do carrapato. Leite e tecidos provenientes de bovinos tratados por um período de 77 a 120 dias com um produto comercial contendo DFB foram analisados quanto à presença de resíduos. Os resíduos de DFB foram determinados utilizando-se extração com acetonitrila, limpeza por SPE C18 e cromatografia líquida de alta eficiência com detecção por UV (254nm). DFB não foi detectado em nenhuma das amostras analisadas (<0.006mg $\mathrm{kg}^{-1}$ para gordura, $<0,014 \mathrm{mg} \mathrm{kg}^{-1}$ para músculo, $<0,015 \mathrm{mg} \mathrm{kg}^{-1}$ para rim, <0,016mg $\mathrm{kg}^{-1}$ para fígado e $<0.0006 \mathrm{mg} \mathrm{kg}^{-1}$ para leite). Dessa forma, a utilização do princípio ativo conforme recomendado pelo fabricante e em níveis suficientes para se obter o efeito larvicida desejado deve resultar em leite, fígado, rins, gordura e músculos que podem ser considerados seguros para o consumo em termos da presença $D F B$.

Palavras-chave: diflubenzurom, larvicida, droga veterinária, tecido bovino, leite

\section{INTRODUCTION}

Diflubenzuron (1-(4-chlorophenyl)-3-(2,6difluorobenzoyl) urea) is a benzoylurea insect growth regulator (IGR) used against larvae of different insects in agriculture and horticulture. It can also be used in cattle breeding in order to prevent cattle tick (Boophilus microplus) and the development of horn fly (Haematobia irritans) infestations, since significant financial losses may result from ectoparasitic infestations such as these. The Diflubenzuron (DFB) mode of action involves the inhibition of the cuticle formation during insect development. It interferes with the synthesis of chitin, one of the components of the insect's cuticle; therefore, the malformed cuticle

Recebido em 2 de maio de 2011 
cannot tolerate the internal pressure during ecdysis and is unable to give support to the muscles involved in the process and are thus incapacitated of discharging exuvia, eventually leading to death (Martins and Silva, 2004; Silva and Mendes, 2002).

In cattle breeding, DFB is usually administered orally to the cattle and its subsequent presence in the treated animal's blood and feces will control infestations by ticks and hinder the development of fly larvae usually found in the manure, breaking the reproductive cycle.

The FAO/WHO Joint Meeting on Pesticide Residues (JMPR) evaluated diflubenzuron in 2001 and the ADI (acceptable daily intake) of $0.02 \mathrm{mg} \mathrm{kg}^{-1} \mathrm{bw}^{-1}$, previously established in 1985, was maintained. According to the JMPR evaluation, DFB presents little acute toxicity when given by different routes (oral, inhalation or dermal). DFB was considered not fetotoxic or teratogenic and also unlikely to be genotoxic or to pose carcinogenic risk to humans (JMPR, 2001).

Although there are three products containing DFB registered at the Ministry of Agriculture, Livestock and Food Supply (MAPA) (CPVS, 2012) in Brazil, there is no maximum residue level (MRL) established for DFB in milk or meat (or any other cattle tissue). On the other hand, Codex Alimentarius establishes MRLs of $0.02 \mathrm{mg}$ $\mathrm{kg}^{-1}$ in milk and $0.1 \mathrm{mg} \mathrm{kg}^{-1}$ in both meat fat and edible offal (Codex Alimentarius, 2009).

There is not much data available regarding the presence of DFB in animal products. Some previous studies with milk (from dairy cows) and tissues (from cows and sheep) did not present concerns regarding the presence of residues deriving from the administration of low doses of DFB to the cattle (Corley et al., 1974; Miller et al., 1976; Ivie, 1978; Tfouni et al., 2007). Nevertheless, the animal's breed and gender, the climate, the animal's feed and the period of treatment in these studies may differ from the ones in the present study. This compound was only recently introduced in Brazil to be used as an insect growth regulator in cattle breeding. Since there is a large consumption of meat and milk by the Brazilian population, it is important to assure that these products are safe regarding the presence of DFB residues.
Different analytical procedures for the determination of DFB and other veterinary drugs and pesticides in several food matrices have been adopted over the years. Nowadays, the QuEChERS (standing for quick, easy, cheap, effective, rugged and safe) method of sample preparation, introduced by Anastassiades et al. in 2003, has been widely used for the analyses of different pesticides and veterinary drugs in several food matrices, using different chromatographic techniques and detectors for the compounds detection and quantification

In this manner, the objectives of the present study were to adapt and validate an analytical methodology involving QuEChERS sample preparation for the analyses of diflubenzuron in cattle tissues and milk, and evaluate the presence of DFB residue in milk and four cattle tissues from animals treated orally with a commercial product containing this compound.

\section{MATERIAL AND METHODS}

Diflubenzuron standard was purchased from Sigma-Aldrich. Organic solvents used in the study (acetonitrile, methanol and dimethylformamide) were HPLC grade and purchased from Tedia. The reagent grade $\mathrm{NaCl}$ (Merck) and anhydrous $\mathrm{MgSO}_{4}$ (purity > 98\%, Synth) were used. The magnesium sulfate was heated in a muffle furnace for $5 \mathrm{~h}$ at $500^{\circ} \mathrm{C}$ for phthalates and moisture removal. Primary secondary amine (PSA) sorbent $(40 \mu \mathrm{m}$ particle size) was obtained from Varian and C18 SPE cartridges were obtained from Agilent Technologies (SampliQ, 500mg - used for tissue samples preparation) and Phenomenex (Strata, $500 \mathrm{mg}$ - used for milk samples). Water was obtained from a Millipore Milli-Q water purification system.

In the present study, 9 bulls and 20 dairy cows were treated with a DFB product available in the Brazilian market (Difly $\mathrm{S} 3^{\circledR}$, Champion Farmoquímico Ltda.). The product, commercialized as a powder containing 3\% of DFB, was added to the mineral salt and given daily to the animals. The product, which has no withdrawal period, was added and mixed in the mineral salt in a proportion of $1.2 \mathrm{~g} \mathrm{~kg}^{-1}$. The animals consumed a mean of $100 \mathrm{~g}$ of the mineral salt a day, which resulted in a daily intake of $30 \mathrm{mg}$ of DFB per animal. Bulls were treated 
with the product for a 120 day period and cows for 77 days.

For the study of cattle tissue, the animals used were male, Nelore breed, with ages from 12 to 36 months, weighing between 360 and $420 \mathrm{~kg}$, and bred in a farm in the city of Ouro Verde de Goiás, GO, Brazil. Animals were slaughtered according to Brazilian regulations (Brazil, 2000) in a slaughterhouse certified and inspected by MAPA in time zero, 12 and 24 hours after interrupting treatment with DFB. Three animals were used in each time point. Tissue samples (kidneys, liver, muscles and fat) were collected, refrigerated and transferred to the laboratory where they were homogenized, frozen and stored $\left(-18^{\circ} \mathrm{C}\right)$ until analysis. Samples were kept stored for no longer than 20 days before analyses.

Milk study involved samples collected from Girolando dairy cows, bred in a farm in the city of Ouro Verde de Goiás, with ages from 3 to 6 years and average milk production of $5 \mathrm{~L} /$ day. Nine of the 20 available cows were randomly selected and milked manually. Milk samples were collected from three different cows in time zero, 12 and 24 hours after the end of treatment with DFB. The 9 raw milk samples were frozen and transferred to the laboratory where they were stored $\left(-18^{\circ} \mathrm{C}\right)$ until analysis. Samples were kept stored for no longer than 20 days before analyses.

Blank samples of kidney, liver, muscle, fat and milk were collected from animals which were not treated with DFB, with the same characteristics as the ones used in the study.

The extraction of DFB from the samples was performed based on QuEChERS sample preparation (Anastassiades et al., 2003) with cleanup done by SPE using C18 cartridges. Samples were weighed $(10 \mathrm{~g})$ and placed in a polypropylene centrifuge tube, water was added in volumes according to Table 1 (in order to achieve a total of $10 \mathrm{~g}$ of water in the sample), the tube was shaken and $10 \mathrm{~mL}$ of acetonitrile was added. The solution was mixed with a vortex for $1 \mathrm{~min}$ and then $4 \mathrm{~g}$ of anhydrous $\mathrm{MgSO}_{4}$ and $1 \mathrm{~g}$ of $\mathrm{NaCl}$ were added. The tube was shaken for 1 min and centrifuged for $10 \mathrm{~min}$ at $3500 \mathrm{rpm}$. For milk samples a $5 \mathrm{~mL}$ aliquot of the upper layer was taken and dried under a stream of nitrogen until $1 \mathrm{~mL}$ for cleanup with SPE cartridge. For tissue samples, a $1 \mathrm{~mL}$ aliquot of the upper layer was taken for SPE cleanup.

Table 1. Water volume added to sample for analysis

\begin{tabular}{cc}
\hline Sample Matrix & $\begin{array}{c}\text { Water added for } \\
10 \mathrm{~g} \text { sample }(\mathrm{mL})\end{array}$ \\
\hline Liver & 5 \\
Kidney & 3 \\
Fat & 10 \\
Muscle & 7 \\
Milk & --- \\
\hline
\end{tabular}

C18 SPE cartridges were previously conditioned with $5 \mathrm{~mL}$ of acetonitrile and cleanup was as follows: 1) milk, muscle and fat: the extract was placed in the cartridge and eluted with $3 \mathrm{~mL}$ of acetonitrile; 2) kidney: the extract was dried under a stream of nitrogen, dissolved in $1 \mathrm{~mL}$ acetonitrile:water $(25: 75, \mathrm{v} / \mathrm{v})$ and placed in the cartridge; $2 \mathrm{~mL}$ of methanol:water $(1: 1, \mathrm{v} / \mathrm{v})$ were applied and discarded, DFB was eluted with $3 \mathrm{~mL}$ acetonitrile; 3) liver: the extract was dried under a stream of nitrogen, dissolved in $1 \mathrm{~mL}$ acetonitrile:water $(25: 75, \mathrm{v} / \mathrm{v})$ and placed in the cartridge; $2 \mathrm{~mL}$ of dimethylformamide:water $(60: 40, \mathrm{v} / \mathrm{v})$ were applied and discarded and DFB was eluted with $3 \mathrm{~mL}$ acetonitrile.

After SPE cleanup, all eluates were dried under a stream of nitrogen, dissolved in $1 \mathrm{~mL}$ acetonitrile, filtered (Millex HV, $0.45 \mu \mathrm{m}$, Millipore) and analyzed by HPLC-DAD.

The analyses were carried out using a Shimadzu HPLC apparatus equipped with a LC20AT quaternary pump, DGU-20A5 in-line degasser, Rheodyne $7725 \mathrm{i}$ injector $(20 \mu \mathrm{L}$ loop), a CTO-10AS VP column oven (at $30^{\circ} \mathrm{C}$ ) and a SPD-M20A diode array detector (detection wavelength set at $254 \mathrm{~nm}$ ). For separation, a C18 column (Nova Pak, Waters, 4.6x300mm, $4 \mu \mathrm{m}$ particle size) was used and the mobile phase, at a flow rate of $1 \mathrm{~mL} \mathrm{~min}^{-1}$, consisted of a gradient of A: water and B: acetonitrile. The gradient was programmed as follows: 0 to $10 \mathrm{~min} 60 \% \mathrm{~B}, 10$ to $12 \mathrm{~min}$ increase to $100 \% \mathrm{~B}, 12$ to $17 \mathrm{~min} 100 \% \mathrm{~B}$, 17 to $19 \mathrm{~min}$ decrease to $60 \% \mathrm{~B}, 19$ to $25 \mathrm{~min}$ $60 \% \mathrm{~B}$.

The validation of the analytical method was performed according to ANVISA (Brazil, 2003) guidelines with the following parameters: linearity and matrix effect, accuracy, precision 
(repeatability and reproducibility), limits of detection and quantification. All the validation analyses were carried out using blank samples of milk and tissues.

Linearity and matrix effect were determined by constructing calibration curves with standard solutions in acetonitrile and in the blank matrix extracts (matrix-matched calibration) in the range of 0.0 to $0.25 \mathrm{mg} \mathrm{L}^{-1}$. These levels correspond to DFB concentrations in the sample ranging from 0 to $2.5 \mathrm{MRL}$. Duplicate injections were made at each of the seven concentration levels. The variation between the expected and the calculated concentration of each point injected was determined and compared to values proposed by ANVISA (Brazil, 2003).

Accuracy and repeatability data were obtained with recovery studies carried out by spiking blank samples of milk and the four tissues with DFB standards at levels of $0.05,0.10$ and $0.15 \mathrm{mg}$ $\mathrm{kg}^{-1}$ (for tissues) and $0.01,0.02$ and $0.03 \mathrm{mg} \mathrm{kg}^{-1}$ (for milk). These values represent $0.5,1.0$ and 1.5 MRL, respectively. Spiked samples were analysed in five replicates. The repeatability of the method was evaluated through the relative standard deviation (RSD, \%) associated to measurements of the compounds performed during recovery tests.

Reproducibility was evaluated by performing another set of recovery tests using the same conditions but in a different period of time. For these tests, a blank fat tissue sample was used and spiked with the same standard levels as previous recovery studies. Tests were performed in three levels, five replicates each.

The limits of detection (LODs) were calculated in accordance with INMETRO (2010) guidelines. For this purpose, seven independent analyses of kidney, liver, muscle and fat blank samples spiked with DFB at a level of $0.05 \mathrm{mg} \mathrm{kg}^{-1}$ and blank milk samples spiked with $0.01 \mathrm{mg} \mathrm{kg}^{-1}$ were performed. The LODs were calculated from the standard deviation of these determinations.

Spiked samples were also used for internal quality control and were analyzed simultaneously with each sample batch.

\section{RESULTS AND DISCUSSION}

Initially, one of the purposes of the present study was to validate QuEChERS sample preparation for the analysis of diflubenzuron in cattle tissue. Tests were done using dispersive solid phase cleanup with PSA and C18 as proposed by the method, nevertheless, during validation it was noticed that the extracts were not sufficiently clean, with chromatograms showing interfering peaks at the retention time of the target compound. Therefore, different tests were performed with SPE cartridges in order to improve cleanup. As a result, the method used in the present study involved extraction with acetonitrile, as suggested by the QuEChERS method, and cleanup by C18 SPE, with different elution parameters applied for the different sample matrixes.

The matrix effect was studied for all animal tissues and milk according to INMETRO (2010) guidelines and no matrix effect was observed for any sample matrix. Thus, the standard external plot, with diflubenzuron standard in acetronitrile, was used for quantification. Calibration curve showed linearity in the concentration range studied, with a correlation coefficient (R) of 0.999. For all calibration curves plotted, using both solvent or matrix extract, all the points presented a deviation between the expected and the calculated concentration varying from $0.15 \%$ to $15.4 \%$, values lower than the ones established by ANVISA (Brazil, 2003) guidelines (15 or $20 \%$, varying according to compound concentration).

Results for accuracy and repeatability are reported in Tab. 2. Recoveries obtained for the different samples ranged from $71.8 \%$ to $105.1 \%$ with $\mathrm{RSD}$ ranging from $1.4 \%$ to $13.0 \%$. These results are satisfactory for determinations at $\mathrm{mg}$ $\mathrm{kg}^{-1}$ levels, showing that the method presents adequate accuracy and repeatability (Brazil, 2003).

Table 2 also presents the LODs and LOQs for DFB in the five matrixes analysed. LODs ranged from 0.0006 to $0.016 \mathrm{mg} \mathrm{kg}^{-1}$, while LOQs were established as $0.05 \mathrm{mg} \mathrm{kg}^{-1}$ and $0.01 \mathrm{mg} \mathrm{kg}^{-1}(0.5$ MRL), for tissues and milk, respectively; which were the lower DFB concentration levels used in the precision and accuracy tests. 
Determination of diflubenzuron...

Table 2. Limit of detection (LOD), limit of quantification (LOQ), recovery (R) and relative standard deviation (RSD) for diflubenzuron in cattle tissues

\begin{tabular}{|c|c|c|c|c|c|}
\hline Tissue & LOD $\left(\mathrm{mg} \mathrm{kg}^{-1}\right)$ & $\mathrm{LOQ}\left(\mathrm{mg} \mathrm{kg}^{-1}\right)$ & Spike level $\left(\mathrm{mg} \mathrm{kg}^{-1}\right)$ & $\mathrm{R}(\%) *$ & $\operatorname{RSD}(\%)^{*}$ \\
\hline \multirow{3}{*}{ Kidney } & \multirow{3}{*}{0.015} & \multirow{3}{*}{0.05} & 0.05 & 80.6 & 12.4 \\
\hline & & & 0.10 & 75.2 & 4.9 \\
\hline & & & 0.15 & 72.5 & 9.2 \\
\hline \multirow{3}{*}{ Liver } & \multirow{3}{*}{0.016} & \multirow{3}{*}{0.05} & 0.05 & 90.2 & 13.0 \\
\hline & & & 0.10 & 89.3 & 11.0 \\
\hline & & & 0.15 & 79.3 & 1.4 \\
\hline \multirow{3}{*}{ Muscle } & \multirow{3}{*}{0.014} & \multirow{3}{*}{0.05} & 0.05 & 105.1 & 9.4 \\
\hline & & & 0.10 & 95.6 & 9.0 \\
\hline & & & 0.15 & 91.0 & 9.7 \\
\hline \multirow{3}{*}{ Fat } & \multirow{3}{*}{0.006} & \multirow{3}{*}{0.05} & 0.05 & 104.5 & 4.0 \\
\hline & & & 0.10 & 87.6 & 12.7 \\
\hline & & & 0.15 & 85.3 & 2.8 \\
\hline \multirow{3}{*}{ Milk } & \multirow{3}{*}{0.0006} & \multirow{3}{*}{0.01} & 0.01 & 74.4 & 3.1 \\
\hline & & & 0.02 & 71.8 & 1.7 \\
\hline & & & 0.03 & 78.3 & 6.6 \\
\hline
\end{tabular}

Reproducibility tests were performed on different days using the blank fat tissue sample. Results are presented in Tab. 3. The analytical method showed reproducibility within acceptable levels, with RSD ranging from $5.4 \%$ to $18 \%$ (maximum permitted of $15 \%$ to $20 \%$, depending on the compound concentration).

Table 3. Results of reproducibility tests. Diflubenzuron levels added to a fat tissue sample, the respective levels determined and relative standard deviation (RSD)

\begin{tabular}{ccc}
\hline Spike level $(\mathrm{mg} / \mathrm{kg})$ & Mean diflubenzuron level $(\mathrm{mg} / \mathrm{kg})(\mathrm{SD})^{*}$ & RSD $(\%)^{*}$ \\
\hline 0.05 & $0.0610(0.0042)$ & 6.8 \\
0.10 & $0.0791(0.0142)$ & 18.0 \\
0.15 & $0.1189(0.0064)$ & 5.4 \\
\hline
\end{tabular}

SD: standard deviation.

$* n=5$

Results for the analytical method validation show that the method used is suitable for the analysis of DFB residues in milk and the four cattle tissues evaluated (kidney, liver fat, and muscle), being able to quantify DFB residues under MRLs established by Codex Alimentarius.

After the animals' treatment with DFB, nine samples of each matrix (tissues and milk) were collected and analyzed for the presence of residues. No DFB residue was detected ( $\angle \mathrm{LOD}$ from Tab. 2) in any of the analyzed tissue samples of kidney, liver, fat and muscle. Residues were also not detected in the nine milk samples collected from the treated dairy cows. As DFB was not detected in the samples, there was no need for using any alternative analytical method to confirm the compound's identity.
Considering that the LODs and LOQs determined in the present study present lower values than the MRL established by Codex Alimentarius for DFB in milk $\left(0.02 \mathrm{mg} \mathrm{kg}^{-1}\right)$, edible offal and meat fat $\left(0.1 \mathrm{mg} \mathrm{kg}^{-1}\right)$ and residues were not detected in any analyzed samples, therefore, samples studied are in accordance with the limits established by Codex.

All tissue and milk samples were collected from the animals after a long period of treatment and within 24 hours of product withdrawal. Since no residue was detected under these conditions, results indicate that there is apparently no need to establish a withdrawal period for the product in both beef cattle and dairy cows. 
Results found in the present study are similar to the ones previously reported by other authors. In a study by Ivie (1978) the fate of radiolabed DFB was studied in a dairy cow after single oral dose of $10 \mathrm{mg} \mathrm{kg}^{-1}$ body weight (resulting in a dose of $3.6 \mathrm{~g}$ of DFB). Tissue samples were analyzed 7 days after the treatment, and as a result the compound was not detected $\left(<0.1 \mathrm{mg} \mathrm{kg}^{-1}\right)$ in the kidney and muscle but was detected in the liver $\left(2.9 \mathrm{mg} \mathrm{kg}^{-1}\right)$. The presence of DFB residue in the liver may be explained by the fact that Ivie (1978) provided the animal with one single high dose of the compound, while in the present study the animals were treated for a long period (four months) with lower daily doses. No data is available regarding the presence of residues in muscle fat, which is a marker selected by Codex for the presence of DFB in cattle, since DFB has low solubility in water and is more likely to accumulate in the fat.

Other authors also analyzed the presence of DFB in milk from treated dairy cows. The results reported are similar to the present ones. Corley et al. (1974) treated a dairy cow with $1 \mathrm{mg} \mathrm{kg}^{-1} \mathrm{bw}^{-1}$ daily and collected milk samples in intervals from 2 to 15 weeks of treatment. After analysis, no DFB residue was detected in the sample $\left(<0.1 \mathrm{mg} \mathrm{kg}^{-1}\right)$. Nevertheless, the LOD of this study is higher than the MRL established by Codex.

Miller et al. (1976) administered different doses of DFB to dairy cows for a period of 4-5 months. When the higher dose of the compound (16mg $\mathrm{kg}^{-1} \mathrm{bw}^{-1}$ ) was fed to the animal, DFB residues were detected in the milk in a level of $0.02 \mathrm{mg}$ $\mathrm{kg}^{-1}$.

Tfouni et al. (2007) analyzed milk from 6 Girolando dairy cows treated daily with $60.2 \mathrm{mg}$ of DFB during a seven-month period. No residue was detected in the samples analyzed. In this previous study the authors used a different method of sample preparation, which presented good results during the validation of the methodology. Nevertheless, the present method also proved to be suitable, and additionally presented some advantages such as being less time consuming, using a smaller amount of solvents, generating less residues, and having lower costs.

\section{CONCLUSIONS}

The analytical method proved to be suitable for DFB analysis in milk and in the cattle tissues studied (kidney, liver, fat, and muscle). Although, when the compound was detected, the use of an additional method for confirming the peak identity would be necessary. The analytical method also proved to be a valid alternative for previous methods used for DFB analysis in these matrices. The DFB dose provided daily to the animals (30 mg/day) is the one indicated by the manufacturer of the product, Difly $\mathrm{S} 3{ }^{\circledR}$, in order to obtain the desired insecticide effect; therefore, data presented indicate that the use of this compound in the suggested doses for achieving a proper insecticide effect may result in milk and liver, kidneys, fat and muscles of cattle to be considered safe regarding the presence of DFB residues.

\section{REFERENCES}

ANASTASSIADES, M.; LEHOTAY, S.J.; STAJNBAHER, D. et al. Fast and easy multiresidue method employing acetonitrile extraction/partitioning and "dispersive solid-phase extraction" for the determination of pesticide residues in produce. $J$. AOAC Int., v.86, p.412-431, 2003.

BRASIL. Ministério da Agricultura, Pecuária e Abastecimento. Instrução normativa $\mathrm{n}^{\circ} 03$, de 17 de janeiro de 2000. Diário Oficial da União, 24 de janeiro de 2000.

BRASIL. Agência Nacional de Vigilância Sanitária (ANVISA). Guia para validação de métodos analíticos e bioanalíticos. Resolução RE $\mathrm{n}^{\circ}$ 899, de 29 de maio de 2003.

CODEX ALIMENTARIUS. Pesticide Residues in Food. 2010. Disponível em: <http://www.codexalimentarius.net/mrls/pestdes/jsp/p est_q-e.jsp> Acessado em: 4 abr. 2010.

CORLEY, C.; MILLER, R.W.; HILL, K.R. Determination of N-(4-chlorophenyl)-N'-(2,6difluorobenzoyl)-urea in milk by high speed liquid chromatography. J. AOAC Int. v.57, p.1269-1271, 1974.

CPVS. Compêndio de Produtos Veterinários SINDAN (2012). Disponível em: <http://www.cpvs.com.br/cpvs/index.html> Acessado em 10 out. 2012. 
FURLANI, R.P.Z.; MARCÍLIO, K.M.; LEME, F.M. et al. Analysis of pesticide residue in sugarcane juice using QuEChERS sample preparation and gas chromatography with electron capture detection. Food Chem., v.126, p.1283-1287, 2011.

INMETRO. 2010. Orientação sobre validação de métodos analíticos. DOQ-CGCRE-008. Revisão 3. Fevereiro/2010.

IVIE, G.W. Fate of diflubenzuron in cattle and sheep. J. Agric. Food Chem., v.26, p.81-88, 1978.

JMPR - Joint FAO/WHO Meeting on Pesticide Residues; Pesticides residues in food 2001. Part II Toxicological. WHO: Geneva, 2001.

LEHOTAY, S.J.; DE KOK, A.; HIEMSTRA, M. et al. Validation of a fast and easy method for determination of residues from 229 pesticides in fruits and vegetables using gas and liquid chromatography and mass spectrometry detection. J. AOAC Int., v.88, p.595-614, 2005.
MARTINS, F.; SILVA, I.G. Avaliação da atividade inibidora do diflubenzuron na ecdise das larvas de Aedes aegypti (Linnaeus, 1762) (Diptera: Culicidae). Rev. Soc. Bras. Med. Trop., v.37, p.135-138, 2004.

MILLER, R.W.; CORLEY, C.; OEHLER, D.D. et al. Feeding TH-6040 to cattle: residues in tissues and milk and breakdown in manure. J. Agric. Food Chem., v.24, p.687-688, 1976.

SILVA, J.J.; MENDES, J. Effect of diflubenzuron on immature stages of Haematobia irritans (L.) (Diptera: Muscidae) in Uberlândia, State of Minas Gerais, Brazil. Mem. Inst. Oswaldo Cruz, v.97, p.679-682, 2002.

TFOUNI, S.A.V.; FURLANI, R.P.Z.; ARAÚJO, J.D. et al. Determination of pesticide residues presence in milk from cows treated with diflubenzuron. Rev. Inst. Adolfo Lutz, v.66, p.230-233, 2007. 